\title{
Desialation of Transferrin by Rat Liver Endothelium
}

\author{
Seiji Irie, Takumi Kishimoto, and Mehdi Tavassoli \\ Veterans Administration Medical Center, University of Mississippi Medical Center, Jackson, Mississippi 39216
}

\begin{abstract}
To examine the role of liver endothelium in desialation of transferrin (TF), pulse-chase studies were done by incubation of either ${ }^{3} \mathrm{H}$ (sialic acid labeled)-, or ${ }^{125} \mathrm{I}$, or ${ }^{59} \mathrm{Fe}$ (protein core labeled)-TF with fractionated liver endothelium. While ${ }^{125}$ I or ${ }^{59} \mathrm{Fe}$ labels were externalized after initial binding and internalization, a large proportion of ${ }^{\mathbf{3}} \mathbf{H}$ label was internalized and remained within the cell. When the supernatant of these experiments was studied by isoelectricfocusing and Ricinus communis agglutinin $\left(\mathbf{R C A}_{120}\right)$ affinity chromatography, generation of asialotransferrin was noted by both techniques. Incubation of liver endothelium with double-labeled TF (sialic acids with ${ }^{3} \mathrm{H}$ and protein core with ${ }^{125} \mathrm{I}$ or ${ }^{59} \mathrm{Fe}$ ) led initially to a concordant uptake of the two labels, which were then dissociated and ${ }^{3} \mathrm{H}$ was retained by the cell. These findings indicate desialation of TF by liver endothelium. The significance of these findings in the pathogenesis of hepatic siderosis is discussed.
\end{abstract}

\section{Introduction}

Transferrin (TF) ${ }^{1}$ is an iron-binding transport glycoprotein with a molecular weight of $\sim 80,000$ and is $6 \%$ carbohydrate (1). There is considerable evidence that TF in the serum is heterogeneous and this heterogeneity has been attributed to the glycan structure of the molecule since its amino acid composition remains constant $(2,3)$. Rat TF has a single biantennary or triantennary oligosaccharide chain with two or three terminal sialic acid residues per molecule (4). There is some evidence to indicate that the heterogeneity of serum TF is due to its total or partial desialation. Desialation of TF has been documented in alcoholism and certain liver diseases and is implied in the pathogenesis of hepatic siderosis $(5,6)$.

We have previously shown that in the liver, specific receptors for TF are mostly located on the endothelial membrane $(7,8)$. Endothelium thereby takes up TF and subsequently releases it again into the medium $(9,10)$, apparently in a modified form. We now provide evidence that the incubation of TF

This work was presented in part to the annual meeting of Clinical Research, May 1986, Washington, D.C. and in part to the First International Symposium on Hemochromatosis, N.Y. Academy of Sciences, April 1987, NY.

Address all correspondence to Dr. Mehdi Tavassoli, Veterans Administration Medical Center, 1500 Woodrow Wilson Drive, Jackson, MS 39216.

Received for publication 13 July 1987 and in revised form 1 February 1988

1. Abbreviations used in this paper: $\mathrm{CP}$, ceruloplasmin; D-PBS, Dulbecco PBS; RCA, Ricinus communis agglutinin; TF, transferrin.

The Journal of Clinical Investigation, Inc.

Volume 82, August 1988, 508-513 with liver endothelium, but not with other TF binding cells, leads to its desialation.

Three lines of evidence are presented in support of this concept. The rat TF molecule was double labeled, its sialic acid residues were labeled with ${ }^{3} \mathrm{H}$, and the protein moiety was labeled with either ${ }^{59} \mathrm{Fe}$ or ${ }^{125} \mathrm{I}$. The kinetic behavior of these labels was subsequently studied after incubation of the molecule with fractionated liver endothelium and evidence was obtained to indicate that the two labels become dissociated in the endothelium. The molecule, labeled either with ${ }^{3} \mathrm{H}$ or ${ }^{125} \mathrm{I}$, was then chased through the endothelium and the released material was subjected to isoelectric focusing as well as affinity chromatography using Ricinus communis agglutinin $\left(\mathrm{RCA}_{120}\right)$-agarose.

\section{Methods}

\section{$T F$ and labeling methods}

Purified rat TF was obtained from Cooper Biomedical, Inc. (Westchester, PA). Its purity had been demonstrated by immunoelectrophoresis and was independently confirmed in our laboratory by isoelectric focusing, which demonstrated two bands (slow and fast) in fully saturated form (11). Human TF was obtained from Calbiochem-Behring Corp., San Diego, CA) and further purified by passing it through a Sephadex G-200 column. The purity was subsequently demonstrated by its migration as a single band on PAGE. Apotransferrin was prepared from TF by sodium ascorbate as described $(7,12)$ and was labeled with either ${ }^{3} \mathrm{H}$ (sialic acids), ${ }^{125} \mathrm{I}$ or, ${ }^{59} \mathrm{Fe}$ protein or both.

The method for double labeling of TF has been described elsewhere in detail (13). Sialic acid residues of apotransferrin were labeled with ${ }^{3} \mathrm{H}$ according to the method of Van Lenten and Ashwell (14) using consecutive oxidation with $\mathrm{NaIO}_{4}$ and reduction with $\mathrm{NaB}^{3} \mathrm{H}_{4}$, which introduces the tritium in the sialic acid residues. $5 \mathrm{mg}$ apotransferrin in $0.5 \mathrm{ml} 0.1 \mathrm{M}$ sodium acetate and, $0.15 \mathrm{M} \mathrm{NaCl}$ (pH 5.6) was first oxidized by incubation with $0.208 \mathrm{ml}$ of $0.012 \mathrm{M} \mathrm{NaIO}_{4}$ for $10 \mathrm{~min}$ at $0^{\circ} \mathrm{C}$. Oxidation was stopped by the addition of an excess of ethylene glycol $(500 \mu \mathrm{l})$ and the solution was dialyzed overnight at $4^{\circ} \mathrm{C}$ against PBS, pH 7.4. Periodate consumption, determined by iodometric titration (15) indicated that $>1.5 \mathrm{~mol}$ of periodate $/ \mathrm{mol}$ of sialic acid was oxidized. This is fairly close to $2 \mathrm{~mol} / \mathrm{mol}$, which is theoretically ideal (14). $1 \mathrm{mg}$ of tritiated $\mathrm{NaBH}_{4}$ (ICN Radiochemicals, Irvine, CA) dissolved in $0.2 \mathrm{ml}$ of $0.01 \mathrm{M} \mathrm{NaOH}$ was added to the oxidized TF solution. After mixing the solution, it was warmed to room temperature and the reduction was allowed to continue for $30 \mathrm{~min}$ with stirring. To insure the completeness of reduction, $3 \mathrm{mg}$ of nonradioactive $\mathrm{KBH}_{4}$ were then added and the incubation continued for another 30 min. Excess borohydrate was removed by dialysis against a solution of $0.1 \mathrm{M}$ sodium acetate and $0.15 \mathrm{M} \mathrm{NaCl}$ (pH 5.6) for several hours before exhaustive dialysis against PBS, pH 7.4. Because glucose, linked nonenzymatically to protein through an aldimine, could also be reduced and labeled by this method (16), we subsequently hydrolyzed the sialic acid moiety of these preparations by either acid hydrolysis or by the enzymatic method (Clostridium perfringens neuraminidase, Sigma Chemical Co., St. Louis, MO) of Van Lanten and Ashwell (14). This demonstrated that, respectively, 91 or $78 \%$ of the label was on sialic acid. Since complete removal of sialic acid by either method is not possible, these data suggest that only sialic acids in these preparations were labeled. 
The protein part of apotransferrin was labeled with ${ }^{125}$ I using lactoperoxidase method (17). When tritiated apotransferrin was labeled, subsequent ${ }^{125}$ I labeling was done with Bolton-Hunter reagent (18) since the usual peroxidation method could theoretically remove the ${ }^{3} \mathrm{H}$ label from sialic acid.

Alternatively, tritiated apotransferrin was saturated with ${ }^{59} \mathrm{Fe}$, using ${ }^{59} \mathrm{Fe}-\mathrm{Cl}_{3}$. Otherwise single- or double-labeled TF was saturated with cold $\mathrm{Fe}$. The methods for these procedures have been described in detail $(7,19,20)$ and will not be repeated here. Hereafter, TF will represent fully-saturated differic holotransferrin unless otherwise specified.

The specific activities of ${ }^{59} \mathrm{Fe},{ }^{125} \mathrm{I}$, and ${ }^{3} \mathrm{H}$ were, respectively, 1.3, 8, and $16 \mu \mathrm{Ci} / \mathrm{nmol}$ for double-labeled ligand. The specific activities of ${ }^{125} \mathrm{I}$ and ${ }^{3} \mathrm{H}$ for single-labeled ligands were 12 and $0.5 \mu \mathrm{Ci} / \mathrm{nmol}$, respectively.

\section{Cell preparations}

Crude liver cell suspensions were obtained from Sprague-Dawley rats, which weighed $150-250 \mathrm{~g}$, using the collagenase perfusion method (8, 9, 21-25). Cells were suspended in Dulbecco PBS (D-PBS) to a final concentration of $4 \times 10^{6} \mathrm{cells} / \mathrm{ml}$. They were partially fractionated into large (hepatocytes) and small cell fractions using metrizamide doublelayer centrifugation as described $(8,9,21-25)$. To further purify endothelial cells, centrifugal elutriation was used $(8,12)$. The endotheliumrich small fraction was suspended in PBS at a concentration of $2 \times 10^{7}$ cells $/ \mathrm{ml}$ and loaded in a Beckman JE6-B standard elutriator rotor (4.2 ml) using a JS-21 centrifuge (Beckman Instruments, Inc., Fullerton, CA). Before cell loading, the rotor was eluted with PBS at a flow rate of $11 \mathrm{ml} / \mathrm{min}$. The rotor was then loaded, using a total volume of $4 \mathrm{ml}$ while maintaining the same flow rate. Elutriation was done at $650 \mathrm{~g}$ at $20^{\circ} \mathrm{C}$. The flow rate was increased to 22 and $300 \mathrm{ml} / \mathrm{min}$ (corresponding to about $2 \times 10^{7}$ cells) of eluant fluid was collected. Cell identification was made by scanning and transmission electron microscopy, as well as by cytochemistry as described $(7,8,22,26)$. Endothelial cell identification was further confirmed by immunofluorescent reaction for Factor VIII antigen using the indirect method as described $(7,8)$. The purity of endothelial cells was $92 \%$ with the remaining cells being Kupffer cells, small lymphocytes, and an occasional bile epithelial cell. We have shown that fractionated Kupffer cells do not have TF receptors (7), nor do unstimulated lymphocytes in our bands have TF receptors. Hepatocytes that have TF receptors were not seen in this fraction. Moreover, hepatocyte TF receptors are apparently sensitive to collagenase and require a $37^{\circ} \mathrm{C}$ incubation for their recovery (25). Viability of endothelial cells (as determined by trypan blue exclusion) was $97 \%$. Viability, which was determined in several experiments after incubation, did not appear to change.

K562 cells were obtained from the American Type Culture Collection (Rockville, MD), grown in RPMI 1640 medium with $10 \%$ heatinactivated fetal bovine serum (Gibco Laboratories, Grand Island, $\mathrm{NY}$ ), and maintained at a density of $5 \times 10^{5}$ cells $/ \mathrm{ml}$. Viability was $>98 \%$ by trypan blue exclusion.

\section{Incubation}

Continuous studies. Endothelium and K562 cells were adjusted to total cell concentration of $10^{7} / \mathrm{ml}$ in D-PBS containing $0.5 \%$ BSA. To $100 \mu \mathrm{l}$ of this suspension ( $10^{6}$ cells), ${ }^{125} \mathrm{I}-{ }^{3} \mathrm{H}$-double-labeled or ${ }^{59} \mathrm{Fe}-{ }^{3} \mathrm{H}$-double-labeled ligand was added to make up the desired concentration, which, from preliminary work, proved to be the saturating concentration for that particular cell type. Incubations were done in microcentrifuge tubes in a total volume of $250 \mu \mathrm{l}$ at $37^{\circ} \mathrm{C}$ for the desired period with gentle shaking to prevent the settling of the cells. All experiments were done in triplicate. To ensure the specificity of the uptake, inhibition control was done by preincubation with 100 -fold concentration of cold TF, 20 min before and during incubation with labeled TF.

The cells were washed three times in cold D-PBS using a microcentrifuge, and the cell-associated radioactivity was determined by using the liquid scintillation counter $\left({ }^{3} \mathrm{H}\right)$ and a gamma counter $\left({ }^{125} \mathrm{I}\right.$, ${ }^{59} \mathrm{Fe}$ ). The nonspecific uptake (uptake in the presence of excess TF) was subtracted from total uptake and this was expressed as specific uptake.

Pulse-chase studies. Endothelial cells were first incubated with ${ }^{125} \mathrm{I}$-, ${ }^{3} \mathrm{H}$-, or ${ }^{59} \mathrm{Fe}$-labeled TF in D-PBS containing $0.5 \%$ BSA at $4{ }^{\circ} \mathrm{C}$ for 30 min to saturate the surface TF receptors. Cells were then washed three times with ice-cold D-PBS to remove unbound TF. Surface-bound TF was then chased by the addition of cold TF through the cell and by incubations in microcentrifuge tubes containing $5 \times 10^{5}$ cells in $250 \mu \mathrm{l}$ (total volume) D-PBS at $37^{\circ} \mathrm{C}$ for varied periods of time with gentle agitation. At the end of the incubation time each cell suspension was centrifuged and the supernatant was obtained by washing the cells twice with $250 \mu \mathrm{l}$ of cold D-PBS. The surface-bound ligand was then determined by fractionating the surface-bound and intracellular ligand with $0.25 \%$ pronase in $500 \mu \mathrm{l}$ D-PBS at $4^{\circ} \mathrm{C}$ for $1 \mathrm{~h}$ according to the method described in detail elsewhere (27), and then the cells were washed twice with $250 \mu \mathrm{l}$ cold D-PBS. The cells were then solubilized in $1 \mathrm{ml}$ of $1 \mathrm{M} \mathrm{NaOH}$ for gamma counting $\left({ }^{125} \mathrm{I},{ }^{59} \mathrm{Fe}\right)$ or in $1 \mathrm{ml}$ of NCS (Amersham Corp., Arlington Heights, IL) for liquid scintillation counting $\left({ }^{3} \mathrm{H}\right)$, and the radioactivities were counted and considered to be intracellular.

\section{$R C A_{120}$-agarose chromatography}

Fractionated endothelial cells were first incubated with ${ }^{125} \mathrm{I}$ or ${ }^{3} \mathrm{H}$-labeled TF. To ensure that the TF used for this incubation was indeed sialated, it was run on an $\mathrm{RCA}_{120}$-agarose column (as described below) and the fraction that was not retained was used for incubation since desialated TF is retained by this column. To bind the ligand to specific membrane receptors, incubation was done with $10^{7}$ endothelial cells at the TF concentration of $150 \mu \mathrm{g} / \mathrm{ml}$ at $4^{\circ} \mathrm{C}$ for $30 \mathrm{~min}$ in $5 \mathrm{ml} \mathrm{D-PBS}$ containing $0.5 \%$ BSA. Cells were then washed three times in ice-cold D-PBS to remove unbound ligand in the medium, and were transferred to $37^{\circ} \mathrm{C}$ to chase the surface-bound ligand through the cell. This incubation was done for $2 \mathrm{~h}$ in a microcentrifuge tube containing $10^{7}$ cells in $250 \mu$ l D-PBS with gentle agitation. The cell suspension was then centrifuged and the supernatant was obtained. Subsequently, the $250 \mu \mathrm{l}$ of the supernatant was subjected to $\mathrm{RCA}_{120^{-} \text {agarose (Sigma }}$ Chemical Co.) column ( $10 \mathrm{~mm} \times 25 \mathrm{~mm})$ chromatography, which was equilibrated with D-PBS ( $\mathrm{pH} 7.4$ ), and was eluted with the same buffer at the flow rate of $2 \mathrm{ml} / \mathrm{h}$ at room temperature into fractions of $400 \mu \mathrm{l}$ each. Retained fraction (radiolabeled ligand) was completely eluted with D-PBS containing 0.2 M $\beta$-D-galactose (Sigma Chemical Co.).

\section{Isoelectric focusing}

${ }^{125}$ I-labeled native iron-saturated rat $\mathrm{TF},{ }^{125} \mathrm{I}$-labeled iron-saturated rat asialo-transferrin (prepared by the neuraminidase method), and the supernatants, which were obtained after the pulse-chase experiment, were subjected to isoelectric focusing using ampholine pagplate (LKB Instruments, Inc., Gaithersburg, MD) with a pH range of 3.5-9.5 that ran at $10^{\circ} \mathrm{C}, 1 \mathrm{~W} /$ sample, and constant power with voltage and current at maximum settings. After a 2-h run the plate was fixed and sliced into 2 -mm width bands and the ${ }^{125}$ I-radioactivity of each band was counted.

\section{Results}

Pulse-chase studies. In pulse-chase studies using ${ }^{125}$ I-labeled TF (Fig. $1 A$ ), surface-bound ligand, which was maximal at the beginning of the $37^{\circ} \mathrm{C}$-incubation period (time zero), declined with incubation time. Meanwhile, intracellular ligand, which was nil at time zero, increased and peaked between 5 and 15 min and gradually decreased for the rest of the 90-min duration of the experiment. On the other hand, extracellular ligand, which was also nil at time zero, increased to reach a plateau at $30 \mathrm{~min}$, suggesting externalization of the labeled ligand. A similar pattern was noted with ${ }^{59} \mathrm{Fe}-$ labeled TF (Fig. $1 B$ ). While a small portion of ${ }^{59} \mathrm{Fe}$ was retained by the cell, a great proportion was externalized. 


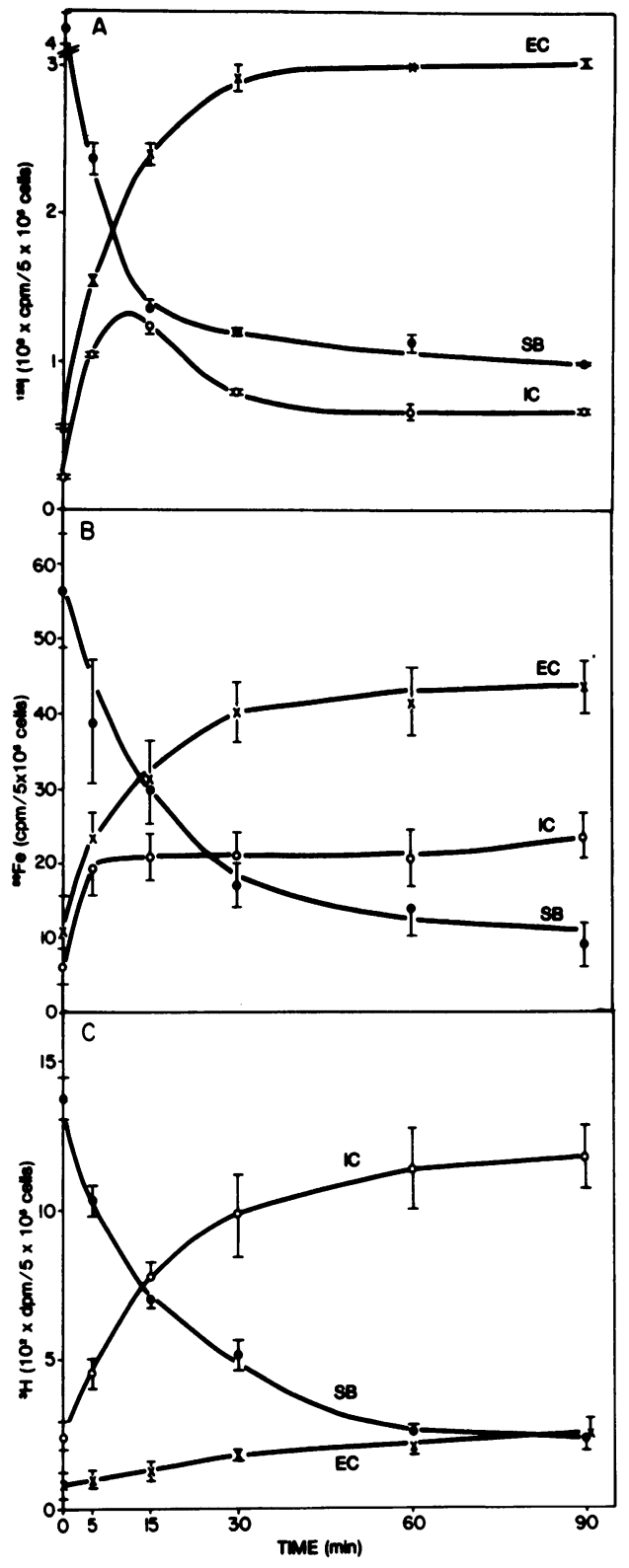

Figure 1. Transcytosis of TF in rat liver endothelial cells. Rat TF was labeled with ${ }^{125} \mathrm{I}(A),{ }^{59} \mathrm{Fe}(B)$ (protein moiety), or with ${ }^{3} \mathrm{H}$ (sialic acid residues) $(C)$ as described in the text. It was incubated with $2 \times 10^{7}$ fractionated endothelial cells at $4^{\circ} \mathrm{C}$ at a concentration of $100 \mu \mathrm{g} / \mathrm{ml}$ in D-PBS, pH 7.4, containing $0.5 \%$ BSA in a total volume of $5 \mathrm{ml}$. Excess unbound ligand was washed off by centrifugation three times with D-PBS. The cells were divided into fractions of $5 \times 10^{5}$ cells each in D-PBS (total volume $250 \mu \mathrm{l}$ ) and were transferred to $37^{\circ} \mathrm{C}$ for the indicated time. The reaction was stopped by the addition of $250 \mu \mathrm{l}$ of ice-cold D-PBS and the supernate was removed quickly by centrifugation. Cells were washed two more times with $250 \mu$ l of icecold D-PBS and were treated with $500 \mu \mathrm{l}$ of D-PBS containing $0.25 \%$ pronase at $4^{\circ} \mathrm{C}$ for $1 \mathrm{~h}$. At the end of pronase treatment, the cells were again washed twice with $250 \mu$ l of ice-cold D-PBS. The radioactivity in the pronase-sensitive (surface-bound, $S B$ ) fraction ( $\bullet$ ), pronase-resistant (intracellular, $I C$ ) fraction (O), and the extracellular $(E C)$ fraction $(x)$ was determined. Data represent mean $\pm \mathrm{SD}(n=3)$.

In pulse-chase studies using ${ }^{3} \mathrm{H}$-labeled TF (Fig. $1 C$ ), surface-bound radioactivity also declined with incubation time in the same manner as ${ }^{125}$ I-labeled TF. However, intracellular radioactivity, which was nil at time zero, increased to reach a plateau at $60 \mathrm{~min}$, while extracellular radioactivity increased only slightly, indicating that sialic acid (the ${ }^{3} \mathrm{H}$ label) was dissociated from TF and retained in the endothelium.

In these experiments $>80 \%$ of extracellular radioactivity of each incubation time was precipitated by TCA, which indicated the absence of significant degradation products.

$R C A_{120}$-agarose chromatography. To remove desialated $\mathrm{TF}$, which might normally be present in the preparations, native labeled rat TF was initially subjected to chromatography on an $\mathrm{RCA}_{120}$ column and $98.4 \%$ of the protein was eluted with the equilibration buffer. Since $\mathrm{RCA}_{120}$ binds terminal galactosyl residues, this fraction was considered to be the sialated form of TF in which penultimate galactosyl residues were covered by terminal sialic acids. About $1.6 \%$ of the protein did not elute with the equilibration buffer and required $0.2 \mathrm{M}$ $\beta$-D-galactose for its elution. This small fraction was considered to be the desialated form of TF and this was confirmed by the absence of ${ }^{3} \mathrm{H}$ label in the elution pattern (Fig. $2 \mathrm{~A}$ ).

The sialated fraction (the segment shown by the double arrow in Fig. $2 \mathrm{~A}$ ) was then collected and concentrated on Amicon (mol wt $>10,000)$. It was then used for pulse-chase

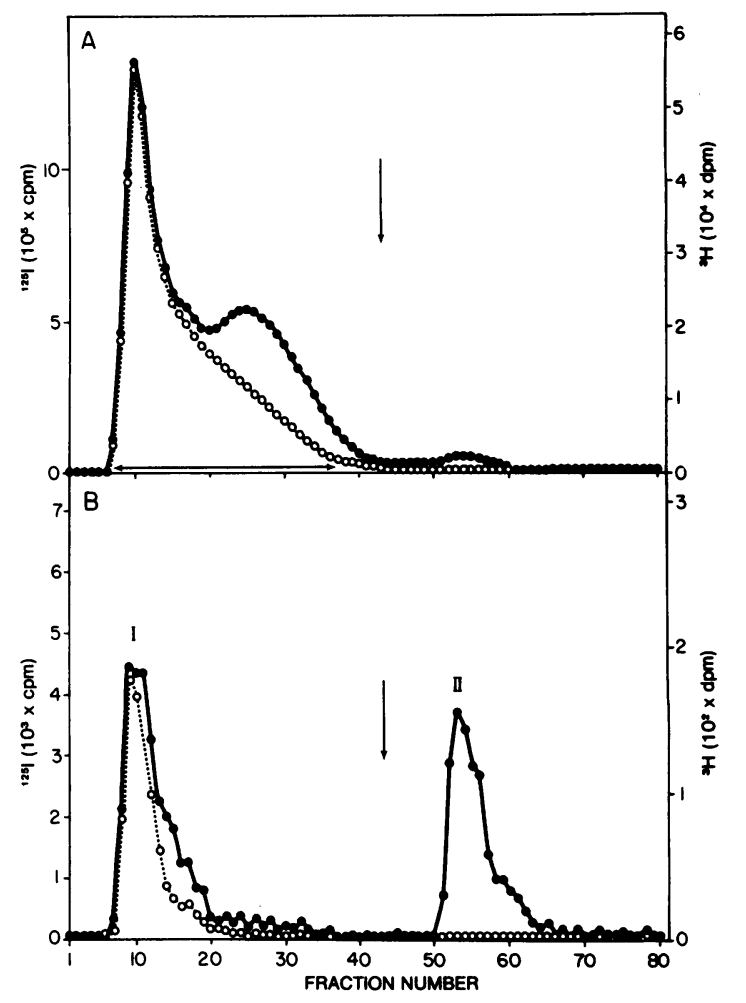

Figure 2. $\mathrm{RCA}_{120}$-agarose chromatographs of $(A)$ native rat $\mathrm{TF}$ and $(B)$ the supernate obtained after pulse-chase experiments with endothelial cells as described above. Sialated TF as indicated by doubleheaded arrow (the peaks before elution) was used for pulse-chase experiment. TF was iron-saturated, labeled with either ${ }^{125} \mathrm{I}$ (protein moiety) (•) or ${ }^{3} \mathrm{H}$ (sialic acid residues) (0), dissolved in $200 \mu \mathrm{l}$ of D-PBS, and applied to the column $(10 \times 25 \mathrm{~mm})$ that was equilibrated with the same buffer. Elution was carried out initially with D-PBS and then with D-PBS containing $0.2 \mathrm{M} \beta$-D-galactose at the flow rate of $2 \mathrm{ml} / \mathrm{h}$ at room temperature. Arrows indicate the application of D-PBS containing $0.2 \mathrm{M} \beta$-D-galactose. The radioactivity of each fraction was determined. Note the generation of asialotransferrin after incubation of sialated TF with endothelial cells. 
incubation with fractionated endothelium as described above. Incubation was done for $2 \mathrm{~h}$ at $37^{\circ} \mathrm{C}$ after the $4^{\circ} \mathrm{C}$ incubation and washing. The supernate from this incubation was again applied to the $\mathrm{RCA}_{120}$ column. Now, $\sim 50 \%$ of the radioactivity in the supernate was retained by the column which required $\beta$-D-galactose for its elution and therefore indicated desialation of the molecule upon the $37^{\circ} \mathrm{C}$ incubation with the endothelium so that the penultimate galactosyl residues had become terminal. This interpretation was further confirmed by the absence of ${ }^{3} \mathrm{H}$ (sialic acid) in the elution pattern (Fig. $2 \mathrm{~B}$ ). To ensure that the surface binding per se did not involve a selective subpopulation of TF, TF was bound to the cell at $4^{\circ} \mathrm{C}$, unbound ligand was washed three times in cold D-PBS, and then the surface-bound ligand was dissociated according to the method of Haigler et al. (28). When this dissociated ligand was run on the $\mathrm{RCA}_{120}$ column, the elution pattern was identical to the segment (shown by the double arrow in Fig. $2 A$ ) used for binding. This indicated that the binding was not selective for a subpopulation of TF.

In these experiments $>80 \%$ of radioactivity of each fraction was precipitated by TCA indicated the absence of signifcant degradation products.

Isoelectric focusing. Isoelectric focusing of the supernate after pulse-chase incubation of TF with endothelium revealed two peaks, one comigrating with asialotransferrin and the other comigrating with the fast band of sialated TF (Fig. 3).

Behavior of double-labeled molecule. Fig. $4 \mathrm{~A}$ shows the time course of both ${ }^{125} \mathrm{I}$ (protein) and ${ }^{3} \mathrm{H}$ (sialic acid) labels after incubation of the double-labeled molecule with liver endothelium at $37^{\circ} \mathrm{C}$. Cell-associated radioactivities for both labels increased concordantly for the first $15 \mathrm{~min}$ in an overlapping manner, which indicated the uptake of the molecule by endothelium. Subsequently the curves for the two labels dissociated, with the cell-associated ${ }^{125}$ I declining while the ${ }^{3} \mathrm{H}$ curve reached a steady state plateau or it even increased somewhat, which suggested an accumulation of the ${ }^{3} \mathrm{H}$ label in the cell. The same tendency was noted when ${ }^{59} \mathrm{Fe}$ and ${ }^{3} \mathrm{H}$ were used as the labels (Fig. 4 B). Again, cell-associated radioactivities increased concordantly for the first $15 \mathrm{~min}$ which indicated the uptake of the molecule by the cells. Subsequently the

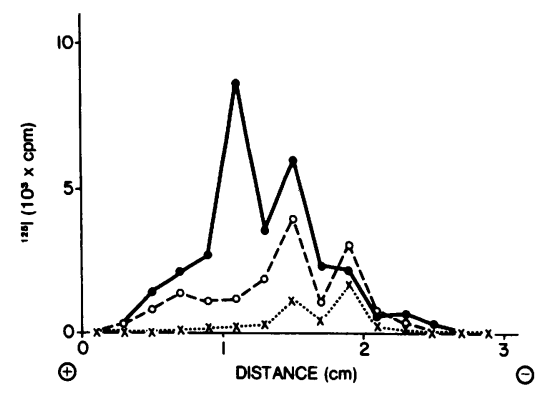

Figure 3. Isoelectric focusing of ${ }^{125} \mathrm{I}$-rat TF. ${ }^{125} \mathrm{I}$-native diferric TF $(\bullet)$, neuraminidase-treated (desialated) diferric TF ( 0 ), and the supernate obtained after the pulse-chase experiment $(x)$ were subjected to isoelectric focusing. The gels were sliced into 2 -mm-wide strips and counted for radioactivity. The numbers indicate the distance from the anode side, which is indicated. Sialated rat TF normally shows two bands (fast and slow) on isoelectric focusing. This is because the protein is a hybrid of two populations containing either biantennary or triantennary glycan chain, thus containing two or three sialyl residues. These two populations are resolved in isoelectric focusing. Note the absence of the slow (triantennary) band of TF in the supernate and the generation of a band comigrating with asialotransferrin. two curves dissociated, with ${ }^{59} \mathrm{Fe}$ declining while ${ }^{3} \mathrm{H}$ reached a plateau or slightly increased to suggest accumulation in the cell. The pattern of decline for ${ }^{125} \mathrm{I}$ and ${ }^{59} \mathrm{Fe}$ labels was similar, which suggests that the two labels were externalized while still in association. No uptake of protein labeled with any of the labels was noted for fractionated hepatocytes or for Kupffer cells.

For the sake of control, another TF receptor-bearing cell type, K562 cells, was used to determine whether this phenomenon is unique to liver endothelium or is a general characteristic of TF receptor-bearing cells. The results are shown in Fig. 5. Both ${ }^{125} \mathrm{I}$ and ${ }^{3} \mathrm{H}$ showed overlapping patterns, increasing in the cell for the first $5 \mathrm{~min}$ and reaching a steady state plateau after $15 \mathrm{~min}$, which indicated the recycling of the molecule in fully sialated form. On the other hand, with the use of ${ }^{59} \mathrm{Fe}$ and ${ }^{3} \mathrm{H}$ labels, ${ }^{59} \mathrm{Fe}$ appeared to accumulate in the cell as a linear function of the time, while ${ }^{3} \mathrm{H}$ reached a steady-state plateau.

\section{Discussion}

These studies implicate liver endothelium as the site of desialation of TF. The pulse-chase experiments using ${ }^{3} \mathrm{H},{ }^{59} \mathrm{Fe}$, or ${ }^{125}$ I-labeled TF support our previous finding $(9,10)$ that liver endothelium mediates the hepatic uptake of TF. Thus, ${ }^{125} \mathrm{I}$-labeled TF binds and is internalized by the endothelium and is subsequently externalized into the medium. A similar pattern is seen with ${ }^{59} \mathrm{Fe}$-labeled TF except that the cell appears to retain part of the iron, probably to satisfy its own needs. That Fe remains in association with TF suggests a transcellular pathway separate from the endosomal pathway where low $\mathrm{pH}$ can dissociate $\mathrm{Fe}$ from TF. However, when ${ }^{3} \mathrm{H}$ is used to label sialic acid residues of TF, internalization of the label is not followed by externalization in the same magnitude as the ${ }^{125} \mathrm{I}$ label. Much of the ${ }^{3} \mathrm{H}$ labels actually remain within the cell, which indicates desialation of TF by endothelium and retention of much of the sialic acids by the cell. In pulse chasing with ${ }^{125} \mathrm{I}$-labeled ligand the extracellular counts rise faster than and before the appearance of intracellular TF. While it is possible that some TF may be coming off the cell without internalization, an alternative explanation would be that transendothelial transport of TF is highly rapid and, in this regard, the endothelial cells may behave differently from such cell systems as the hepatoma cell line (29).

Similarly, when the molecule is double labeled with ${ }^{3} \mathrm{H}$ and with either ${ }^{125} \mathrm{I}$ or ${ }^{59} \mathrm{Fe}$, liver endothelium takes up both labels concordantly. The two labels then diverge and sialic acid appears to be partially retained by the cell while the remaining part of the molecule may be released from the cell. That there is no linear accumulation of ${ }^{3} \mathrm{H}$ label, as may occur with ${ }^{59} \mathrm{Fe}$ in other cell systems $(11,21,30-32)$, suggests that the retention of sialic acid may not be complete. Generation of desialated TF after incubation with liver endothelium was also demonstrated in the present study by isoelectric focusing of the supernatant, which demonstrated a band comigrating with asialotransferrin. Moreover when the supernate was subjected to RCA $_{120}$ affinity column, a desialated component was found which was not present in the TF used initially for incubation with endothelium.

The cellular site of desialation is not evident from this work. We have previously demonstrated that sialated TF is internalized by endothelium. This is not only shown in morphologic studies using an electron microscopic label (9), but also by fractionation of surface-bound and internalized ligand 


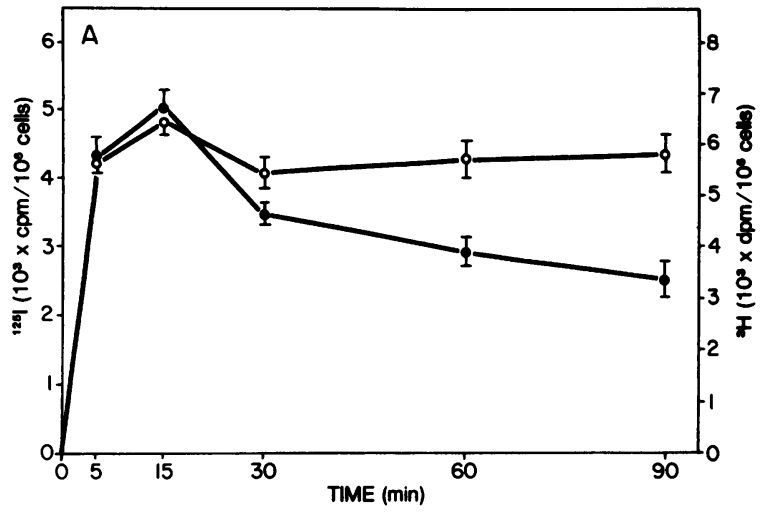

Figure 4. Incubation of double-labeled rat TF with rat liver endothelial cells. ${ }^{125} \mathrm{I}$ (protein moiety), ${ }^{3} \mathrm{H}$ (sialic acid residues)-TF $(A)$, or ${ }^{3} \mathrm{H}$ (sialic acid residues). ${ }^{59} \mathrm{Fe}-\mathrm{TF}(B)$ was incubated at $37^{\circ} \mathrm{C}$ with $10^{6} \mathrm{en}$ dothelial cells in $250 \mu \mathrm{l}$ of D-PBS (pH 7.4) containing 0.5\% BSA at the concentration of $100 \mu \mathrm{g} / \mathrm{ml}$. At the indicated times, the cells were washed three times in $250 \mu \mathrm{l}$ of ice-cold D-PBS and the cell-associated radioactivities $\left[{ }^{125} \mathrm{I}(\bullet) ;{ }^{3} \mathrm{H}(0)\right.$, and $\left.{ }^{59} \mathrm{Fe}(\mathrm{x})\right]$ were determined.

using pronase treatment (7). Both methods indicate that after a $37^{\circ} \mathrm{C}$ incubation, TF enters the cell and then is externalized. Time course electron microscopic studies (9) also indicate a directional movement from the luminal side to the space of Disse. Desialation must occur somewhere along this pathway. That in our double-labeled experiment, ${ }^{3} \mathrm{H}$-labeled sialic acid remains cell associated, suggests the possibility that desialation must occur intracellularly. However, the possibility of an ectoenzyme can not be ruled out. To further explore the site of desialation, we are currently obtaining various subcellular fractions for incubation with double-labeled sialated TF. Studies are also underway to detect the localization of neuraminidase-like activity in endothelial cells by electron microscopic cytochemistry. These studies should clarify the subcellular site of desialation.

It is of interest that another plasma glycoprotein, ceruloplasmin (CP), also binds to liver endothelium and undergoes transcytosis and that during this process, the molecule becomes fully desialated (33-35). Subsequent to externalization, desialated molecules are removed by hepatocytes apparently

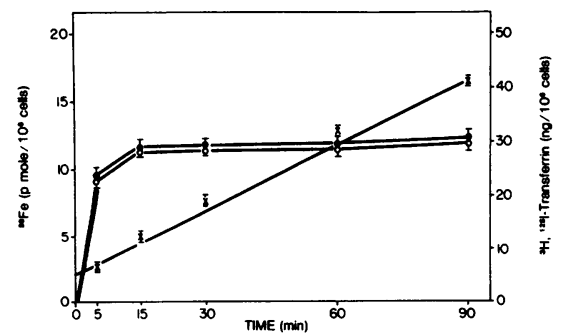

Figure 5. Incubation of double-labeled rat TF with K562 cells. ${ }^{125} \mathrm{I}$ (protein moiety), ${ }^{3} \mathrm{H}$ (sialic acid residues)-TF, or ${ }^{3} \mathrm{H}$ (sialic acid residue). ${ }^{59} \mathrm{Fe}-\mathrm{TF}$ was incubated with $10^{6}$ midlog phase $\mathrm{K} 562$ cells at $37^{\circ} \mathrm{C}$ in $250 \mu$ l of D-PBS (pH 7.4) containing $0.5 \%$ BSA at the concentration of $8 \mathrm{~g} / \mathrm{ml}$. At the indicated times, the cells were washed three times in $250 \mu \mathrm{l}$ of ice-cold D-PBS and the cell-associated radioactivity $\left[{ }^{125} \mathrm{I}(\bullet),{ }^{3} \mathrm{H}(0)\right.$, and $\left.{ }^{59} \mathrm{Fe}(\times)\right]$ was determined. Data represent mean $\pm \mathrm{SD}(n=3)$ of specific uptake. Because the patterns of ${ }^{3} \mathrm{H}$ radioactivity were almost completely identical between two separate experiments using ${ }^{125} \mathrm{I},{ }^{3} \mathrm{H}-\mathrm{TF},{ }^{3} \mathrm{H}$, and ${ }^{59} \mathrm{Fe}-\mathrm{TF}$, these two figures were superimposed for the sake of simplicity.

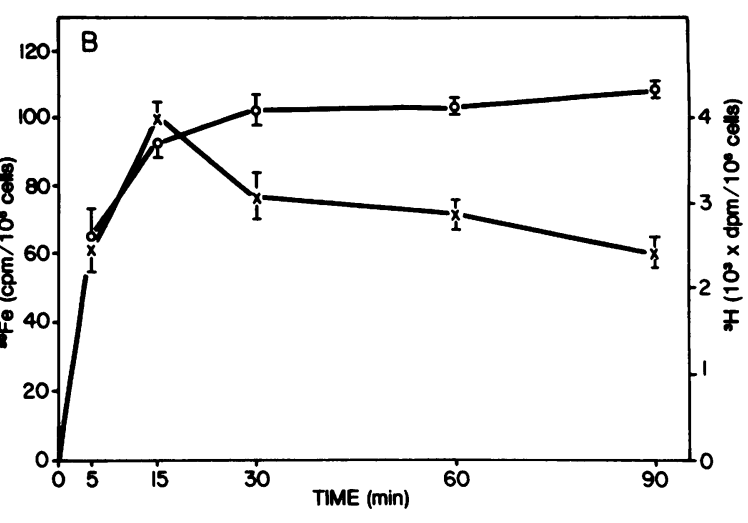

To ensure the specificity of the uptake, inhibition control was done by preincubation with 100 -fold concentration of cold TF, 20 min before and during the incubation with labeled TF. The nonspecific uptake (uptake in the presence of excess TF) was subtracted from total uptake and this was expressed as specific uptake. Data represent mean $\pm \mathrm{SD}(n=3)$.

via membrane asialoglycoprotein receptors of the latter cells. Thus, this mode of hepatic uptake of plasma glycoproteins may be general in nature and the present study lends further support to the notion that hepatocyte asialoglycoprotein receptors may have a physiological function.

There are differences, however, between TF and CP in this regard; whereas CP is fully desialated by endothelium (36), our present chromatographic and isoelectric focusing data indicate that only about $50 \%$ of TF is desialated. It is not clear if there is a certain subpopulation of TF that is susceptible to desialation or if, perhaps, two different transcellular pathways may be involved. This area deserves further studies. Moreover, we have previously demonstrated that $(10)$ when the supernate from incubation of TF with endothelium is subsequently incubated with fractionated purified hepatocytes, it binds. This binding, however, is only partially inhibitable with the asialoglycoprotein, asialofetuin. Thus, while hepatocyte asialoglycoprotein receptors may somehow be involved in the subsequent uptake of desialated TF, the case for TF is not as clear cut as it is with CP. This is also evident from the observation that in vitro desialation significantly reduces the half-life of intravenously infused asialoceruloplasmin but not that of asialotransferrin (37). Studies are underway to fractionate the sialated and desialated TF in the supernate, subject them to carbohydrate structural analysis, and perform binding studies of the two separate fractions to hepatocytes in comparison with other asialoglycoproteins.

All these findings support the notion that liver endothelium is the site of desialation of TF and they may explain the heterogeneity of serum TF with regard to its sialic acid content. Previous reports $(5,6,38)$ have indicated that in certain conditions, such as alcoholism, the sialic acid content of TF is reduced and that this reduction correlates with hepatic siderosis. It is, therefore, possible that desialated TF can enter the hepatocyte via a pathway different from the sialated form that enters the cell via TF receptor, which can recycle. In this context, the present study also assigns a potential role for liver endothelium in liver metabolism of iron in general and in hepatic disorders in particular.

These studies also indicate that TF binding cells are at least of two different types with regard to iron metabolism. One cell 
type is exemplified by $\mathrm{K} 562$ cells. TF binding by this cell type is primarily for the purpose of obtaining iron for its various functions. Consequently, iron dissociates from TF within the cell; iron is retained while apotransferrin is recycled. No desialation occurs during this process. Thus ${ }^{3} \mathrm{H}$ and ${ }^{125} \mathrm{I}$ labels behave concordantly, both reaching a steady state plateau while ${ }^{59} \mathrm{Fe}$ label increases steadily as a function of time. The other cell type, exemplified by liver endothelium, transports iron across the cell without dissociation of iron from TF occurring in the process. TF, however, can be modified in the process. In the case of liver endothelium, this modification is by desialation. Thus, ${ }^{59} \mathrm{Fe}$ and ${ }^{125} \mathrm{I}$ labels behave concordantly and do not dissociate from each other while the ${ }^{3} \mathrm{H}$ label diverges after its initial uptake.

\section{Acknowledgments}

Supported by National Institutes of Health grant DK-30142 and Veterans Administration Research Funds.

\section{References}

1. Huebers, A. H., and C. A. Finch. 1984. Transferrin: physiologic behavior and clinical implications. Blood. 64:763-767.

2. Regoeczi, E., P. Taylor, M. W. C. Hatton, K. L. Wong, and A. Koj. 1978. Distinction between binding and endocytosis of human asialo-transferrin by the rat liver. Biochem. J. 174:171-178.

3. Regoeczi, E., P. Taylor, M. T. Debanne, L. Marz, and M. W. C. Hatton. 1979. Three types of human asialo-transferrin and their interactions with the rat liver. Biochem. J. 184:399-407.

4. Schreiber, G., H. Dryburgh, A. Millership, Y. Matsuda, A. Inglis, J. Phillips, K. Edwards, and J. Maggs. 1979. The synthesis and secretion of rat transferrin. J. Biol. Chem. 254:12013-12019.

5. Regoeczi, E., P. A. Chindemi, and M. T. Debanne. 1984. Transferrin glycans: a possible link between alcoholism and hepatic siderosis. Alcohol. Clin. Exp. Res. 8:287-292.

6. Stibler, H., and S. Borg. 1981. Evidence of reduced sialic acid content is serum transferrin in male alcoholics. Alcohol. Clin. Exp. Res. 5:545-549.

7. Kishimoto, T., and M. Tavassoli. 1985. Endothelial binding of transferrin in crude and fractionated liver cell suspensions. Biochim. Biophys. Acta. 846:14-20.

8. Soda, R., and M. Tavassoli. 1984. Liver endothelium and not hepatocytes or Kupffer cells have transferrin receptors. Blood. 63:270-276.

9. Kishimoto, T., and M. Tavassoli. 1987. Transendothelial transport (trancytosis) of iron-transferrin complex in the liver. Am. J. Anat. 178:241-249.

10. Tavassoli, M., T. Kishimoto, R. Soda, M. Kataoka, and K. Harjes. 1986. Liver endothelium mediates the uptake of iron-transferrin complex by hepatocytes. Exp. Cell Res. 165:369-379.

11. Okada, S., B. Jarvis, and E. G. Brown. 1979. In vivo evidence for the functional heterogeneity of transferrin-bound iron. V. Isotransferrins: an explanation of the Fletcher-Huehns phenomenon in the rat. J. Lab. Clin. Med. 93:189-198.

12. Zahlten, R. N., H. K. Hagler, N. T. Nejtek, and C. J. Day. 1978. Morphological characterization of Kupffer and endothelial cells of rat liver isolated by counterflow elutriation. Gastroenterology. 75:80-87.

13. Kishimoto, T., and M. Tavassoli. 1986. Double-labeling of transferrin: tritium labeling of sialic acid and ${ }^{125} \mathrm{I}$ or ${ }^{59} \mathrm{Fe}$ labeling of the protein moiety. Anal. Biochem. 153:324-329.

14. Van Lenten, L., and G. Ashwell. 1971. The binding of desialated glycoproteins by plasma membranes of rat liver. Development of a quantitative inhibition assay. J. Biol. Chem. 245:1889-1894.

15. Dyer, J. R. 1956. Methods of Biochemical Analysis. Vol. III. Interscience Publishers, Inc. New York, 111-152.
16. Bunn, H. F., R. Shapiro, M. McManus, L. Garrick, M. J. McDonald, M. Gallop, and K. H. Gabbay. 1979. Structural heterogeneity of human hemoglobin A due to non-enzymatic glycosylation. $J$. Biol. Chem. 254:3892-3898.

17. David, G. S. 1972 . Solid state lactoperoxidase: a highly stable enzyme for simple, gentle iodination of proteins. Biochem. Biophys. Res. Commun. 48:464-471.

18. Bolton, A. E., and W. M. Hunter. 1973. The labeling of proteins to high specific radioactivities by conjugation to a ${ }^{125}$ I-containing acylating agent. Biochem. J. 133:529-538.

19. Takahashi, K., and M. Tavassoli. 1982. Biphasic uptake of iron-transferrin complex by L1210 Murine leukemia cells and rat reticulocytes. Biochim. Biophys. Acta. 685:6-12.

20. Van Renswoude, J., K. R. Bridges, J. B. Harford, and R. D. Klausner. 1982. Receptor mediated endocytosis of transferrin and the uptake of $\mathrm{Fe}$ in $\mathrm{K} 562$ cells: identification of a non-lysosomal acidic compartment. Proc. Natl. Acad. Sci. USA. 79:6186-6190.

21. Seglen, P. O. 1976. Preparation of isolated rat liver cells. Methods Cell Biol. 13:29-83.

22. Soda, R., and M. Tavassoli. 1983. Distribution of insulin receptor in liver cell suspension: highest density is on an endothelial-like cell. Exp. Cell Res. 145:389-395.

23. Soda, R., and M. Tavassoli. 1984. Insulin uptake by liver endothelium. Mol. Cell. Biochem. 65:117-123.

24. Soda, R., M. Tavassoli, and D. W. Jacobsen. 1985. Receptor distribution and the endothelial uptake of transcobalamin II in liver cell suspensions. Blood. 65:795-802.

25. Kishimoto, T., and M. Tavassoli. 1986. Recovery of transferrin receptors on hepatocyte membrane af collagenase perfusion. Biochem. Biophys. Res. Commun. 134:711-715.

26. Kataoka, M., and M. Tavassoli. 1984. Ceruloplasmin receptors in liver cell suspensions are limited to the endothelium. Exp. Cell Res. 155:232-240.

27. Iacopetta, B. J., ain E. H. Morgan. 1983. The kinetics of transferrin endocytosis and is:a uptake from transferrin in rabbit reticulocytes. J. Biol. Chem. 2:8:9:08-9115.

28. Haigler, H. T., I. R. Maxfield, M. C. Willingham, and I. Pastan. 1980. Dansylcadaveriri inhibits internalization of ${ }^{125} \mathrm{I}$ epidermal growth factor in BALB $3\lceil 3$ cells. J. Biol. Chem. 255:1239-1241.

29. Ciechanover, A., A. L. Schwartz, A. Dautry-Varsat, and H. F. Lodish. 1983. Kinetics of internalization and recycling of transferrin and the transferrin receptor in a human hepatoma cell line. Effect of lysosomotropic agents. J. Biol. Chem. 258:9681-9689.

30. Karin, M., and B. Mintz. 1981. Receptor mediated endocytosis of transferrin in developmentally totipotent mouse teratocarcinoma stem cells. J. Biol. Chem. 256:3245-3252.

31. Klausner, R. D., J. V. Renswounde, G. Ashwell, C. Kempf, A. N. Schechter, A. Dean, and K. R. Bridges. 1983. Receptor-mediated endocytosis of transferrin in K562 cells. J. Biol. Chem. 258:47154724.

32. Kohno, H., and R. Tokunaga. 1985. Transferrin and iron uptake by rat reticulocytes. J. Biochem. 97:1181-1188.

33. Kataoka, M., and M. Tavassoli. 1985. The role of liver endothelium in the binding and uptake of ceruloplasmin: studies with colloidal gold probe. J. Ultrastruct. Res. 90:194-202.

34. Tavassoli, M. 1985. Liver endothelium binds, transports and desialates ceruloplasmin (CP) which is then recognized by galactosyl receptors of hepatocytes. Trans. Assoc. Am. Physicians. 98:370-377.

35. Tavassoli, M., T. Kishimoto, and M. Kataoka. 1986. Liver endothelium mediates the hepatocytes' uptake of ceruloplasmin. $J$. Cell Biol. 102:1298-1303.

36. Irie, S., and M. Tavassoli. 1986. Liver endothelium desialates ceruloplasmin. Biochem. Biophys. Res. Commun. 140:94-100.

37. Ashwell, G., and A. G. Morell. 1974. The role of surface carbohydrates in the hepatic recognition and transport of circulating glycoproteins. Adv. Enzymol. Relat. Areas Mol. Biol. 41:99-128.

38. Storey, E. L., G. J. Anderson, U. Mack, L. W. Powell, and J. W. Halliday. 1987. Desialated transferrin as a marker of chronic excessive alcohol ingestion. Lancet. i:1292-1293. 